\title{
MENINGKATKAN KUALITAS DAN PREFERENSI KONSUMEN TELUR ITIK DENGAN CARA MENURUNKAN LEVEL BAU AMIS TELUR ASIN YANG DIPERKAYA ANTIOKSIDAN DAUN JINTAN (Plectranthus amboinicus L SPRENG)
}

\section{INCREASING SALTY EGGS QUALITY AND CONSUMER PREFERENCE BY DECREASING ODOR WITHIN ANTIOXIDANT OF Plectranthus amboinicus L SPRENG}

\author{
Ristina Siti Sundari**1, Andri Kusmayadi ${ }^{1}$, Reny Hidayati ${ }^{1}$, Adnan Arshad ${ }^{2}$ \\ ${ }^{1}$ Universitas Perjuangan, J1. PETA No. 177 Tasikmalaya 46115 \\ ${ }^{2}$ China Agricultural University, Beijing 100193, P.R of China \\ *E-mail: ristina.sitisundari@yahoo.com \\ (Diterima 29-06-2020; Disetujui 25-07-2020)
}

\begin{abstract}
ABSTRAK
Kelangkaan supply chain produk pangan memaksa kita terus melakukan diversifikasi untuk menjaga ketahanan pangan. Telur merupakan salah satu komoditas untuk menjaga ketahanan pangan tersebut. Bau amis telur itik seringkali menjadi penyebab kurangnya minat masyarakat untuk mengkonsumsi telur itik. Padahal kandungan gizinya lebih tinggi dari telur ayam. Salah satu alternatif adalah menggunakan daun jintan (Plectrantus amboinicus). Daun jintan memiliki potensi menghilangkan bau amis pada telur itik karena memiliki kandungan bioflavonoid, fenol dan atsiri yang khas. Zat ini diduga dapat menurunkan tingkat keamisan pada telur itik. Penelitian dilakukan untuk mengetahui konsentrasi daun jintan mulai bisa menurunkan bau amis pada daging dan telur itik. Penelitian menggunakan metoda eksploratif experiment Rancangan Acak Kelompok yang diulang 4 kali. Bau amis pada daging dan telur itik berkurang mulai dosis yang paling kecil. Bau amis tersebut semakin berkurang dengan meningkatnya dosis daun jintan yang diberikan. Tetapi kita tidak perlu sampai batas maksimal pemberian daun jintan tetapi sampai batas bau amisnya hilang. Dosis atau konsentrasi yang paling sesuai menurut responden adalah pada dosis 50 gram untuk 40 butir telur. Preferensi konsumen terhadap telur asin bebas amis lebih tinggi daripada yang konvensional. Ada keuntungan lain, telur itik menjadi lebih awet dan mutunya lebih baik. Temuan ini memberikan peluang usaha baru dan varian produk dari yang sudah ada.
\end{abstract}

Kata kunci: Diversifikasi, Ketahanan pangan, Telur itik, Bau amis

\section{ABSTRACT}

Food supply chain scarcity comes to the pinch and coerces us to make any food diversification for food security's sake. The eggs are one of the commodities to keep secure. Otherwise, the fish odor of duck egg often become caused by people less interest to consume duck egg. Instead, it has a higher nutrient composition than chicken as well. One of the alternate ways is Jintan leaf (Plectranthus amboinicus). Jintan leaf has the potency to eliminate odor sensory toward duck egg due to its bioflavonoid, phenol, volatile compound. This substance hypnotized could decrease and eliminate odor levels in duck egg. The research was carried out to know the most proper jintan leaf concentrations to eliminate salty duck egg odor. It used an explorative experimental method by Complete Block Design with three replication and continued by orthogonal contrast test to know which component is more prefer according to consumers. The odor of salty duck eggs decreased and began to decrease even at the 25-gram concentrate. Within the higher concentration, the higher decrease in odor sensory. For the economic aspect, we are not necessary to close in the highest concentration, but we suggest at the early odor sensory is disappeared, by 50 grams for 40 salty duck eggs. There is the other advance to further research, such as prolonging quality. This 
MENINGKATKAN KUALITAS DAN PREFERENSI KONSUMEN TELUR ITIK DENGAN CARA

MENURUNKAN LEVEL BAU AMIS TELUR ASIN YANG DIPERKAYA ANTIOKSIDAN DAUN JINTAN

(Plectranthus amboinicus L SPRENG)

Ristina Siti Sundari, Andri Kusmayadi, Reny Hidayati, Adnan Arshad

finding would be beneficial to producer and consumer and also researcher as the new variance of product.

Keywords: Diversification, Duck egg, Food Security, Odor

\section{PENDAHULUAN}

Level protein dan kolesterol daging dan telur unggas sering diindikasikan dengan tingkat bau amis. Menurut Matitaputty dan Suryana (2010), terjadinya kerusakan akibat reaksi oksidasi dengan udara. Semakin amis suatu bahan maka kandungan nutrisi terutama proteinnya semakin tinggi. Bau amis dari daging dan telur itik bersumber dari kandungan lemak dan proteinnya (Prawoto, 2001) sehingga masyarakat yang menggemarinya tidak sebanyak konsumen daging dan telur ayam. Pengembangan potensi itik juga tidak seintens potensi ayam yang didukung perusahaan-perusahaan unggas baik nasional maupun internasional. Upaya untuk menghilangkan bau amis pada ikan atau daging telah banyak dilakukan seperti dengan menggunakan cuka, ketumbar, jahe, kunyit, jeruk nipis dan asam namun masih menyisakan bahan penambah tersebut.

Total kandungan polyphenol dianggap sebagai indikator ukuran kualitas khasiat atau afektifitas antioksidan suatu herb plant dalam membunuh bakteri (Hii dkk. 2009,
Hasanah, 2016), virus dan jamur, anti radang (Muniroh, dkk. 2013) serta mengendalikan aroma atau bau suatu bahan. Polyphenol ini yang menciptakan bioflavonoid, asam organic, ester, asam capeic dan asam phenolic berperan sebagai antioksidan yang mengikat radikal bebas. Juga dapat menghambat aktivitas enzim proteolitik dan menghambat pertumbuhan bakteri pembusuk sehingga bahan pangan lebih awet (Silalahi, 2018).

Zat polyphenol yang terdapat pada daun jintan adalah minyak astiri yang terdiri atas bioflavonoid, fenol, fitosterin B, isoprophil-o-cresol, carvacrol, tymol (Norazsida, dkk. 2017). Zat-zat khusus yang dikandung daun jintan tersebut diduga bisa dimanfaatkan untuk menghilangkan bau amis pada telur dan daging itik tanpa mengurangi rasa bahan bakunya dan berperan sebagai penguat rasa pada suatu bahan makanan. Pengalaman menunjukkan bahwa semuanya dapat menekan bau amis pada telur itik. Namun demikian, belum diketahui dengan pasti pada konsentrasi berapa daun jintan mulai bisa menurunkan bau amis pada daging dan 
telur itik. Hal ini juga merupakan peluang bagi masyarakat, baik konsumen maupun produsen untuk, meningkatkan karakteristik organoleptik dan mutu bahan pangan itik.

Upaya untuk menghilangkan bau amis telah banyak dilakukan seperti cuka, ketumbar, jahe, kunyit, jeruk nipis dan asam. Namun, masih bermasalah dengan rasa dari bahan tersebut. Perlu dicari alternatif penggunaan bahan alami tambahan yang dapat menghilangkan bau amis namun tidak menghilangkan. Penelitian ini dilakukan untuk menurunkan level bau amis pada telur. Berdasarkan hal tersebut, perlu dilakukan penelitian pemanfaatan daun jintan untuk menurunkan bau amis pada telur itik khususnya itik cihateup yang menurut Matitaputty dan Suryana (2014), Dudi (2007) merupakan sumberdaya genetik unggas lokal unggul yang potensial untuk dijaga keberlangsungannya. Urgensi dari penelitian ini adalah meningkatkan distribusi dan konsumsi unggas lokal yang lebih baik dan menjaga kelestarian unggas unggulan asli Indonesia, khususnya asli Tasikmalaya.

\section{METODE PENELITIAN}

Penelitian ini dilakukan di Universitas Perjuangan pada tahun 2019.
Jenis penelitian bersifat eksploratif eksperimen dan metode campuran (Mixed Method) kuantitatif dan kualitatif. Data dikumpulkan dari responden yang menilai level bau amis telur itik pada berbagai perlakuan penambahan daun jintan dengan dosis daun jintan sebagai variabel.

Variabel perlakuan adalah dosis daun jintan terdiri atas A (0 g), B (25 g), C (50 g), D (75 g), E (100 g), F (125 g), G (150g). Masing-masing perlakuan diulang 3 kali. Model persamaan yang sesuai untuk penelitian ini adalah model (Vincent Gasper, 2011) tetap karena hanya terdiri atas tujuh perlakuan yang tersedia. Model tersebut adalah:

$$
Y_{i j}=u+t_{i}+r_{j}+e_{i j}
$$

Keterangan:

$\mathrm{Y}_{\mathrm{ij}}=$ hasil pengamatan $\mathrm{ke} \mathrm{j}$ yang memperoleh perlakuan ke i

$\mathrm{u}=$ rat-rata populasi pengamatan

$\mathrm{t}_{\mathrm{i}}=$ pengaruh perlakuan ke $\mathrm{i}$

$r_{j}=$ pengaruh ulangan ke $j$

$\mathrm{e}_{\mathrm{ij}}=$ pengaruh galat percobaan pada pengamatan ke $\mathrm{j}$ yang memperoleh perlakuan ke i

Kaidah pengujian:

Jika $\mathrm{F}_{\text {hitung }} \leq$ Signifikansi maka perlakuan tidak berbeda nyata. $\mathrm{H}_{0}$ diterima.

Jika $F_{\text {hitung }}>$ Signifikansi maka perlakuan berbeda nyata. $\mathrm{H}_{0}$ ditolak.

Jika hasil uji keragaman signifikan maka dilanjutkan analisis uji gugus perlakuan 
MENINGKATKAN KUALITAS DAN PREFERENSI KONSUMEN TELUR ITIK DENGAN CARA

MENURUNKAN LEVEL BAU AMIS TELUR ASIN YANG DIPERKAYA ANTIOKSIDAN DAUN JINTAN

(Plectranthus amboinicus L SPRENG)

Ristina Siti Sundari, Andri Kusmayadi, Reny Hidayati, Adnan Arshad

dengan teknik uji orton-gonal kontras.

Gugus perlakuan disusun menjadi

komponen-komponen di bawah ini:

-Komponen 1: A Vs B, C, D, E, F, G.

-Komponen 2: B Vs C, D, E, F, G.

-Komponen 3: C Vs D, E, F, G.

-Komponen 4: D Vs E, F, G.

-Komponen 5: E Vs F, G.

-Komponen 6: F Vs G.

Kemudian membuat susunan koefisien orthogonal kontras sesuai komponen seperti Tabel 1.

Tabel 1. Susunan Koefisien Ortogonal Kontras

\begin{tabular}{ccccccccc}
\hline \multirow{2}{*}{ Komponen } & \multicolumn{7}{c}{ Koefisien (b) } & \multicolumn{1}{c}{$\mathrm{b}^{2}$} \\
\cline { 2 - 7 } & $\mathrm{A}$ & $\mathrm{B}$ & $\mathrm{C}$ & $\mathrm{D}$ & $\mathrm{E}$ & $\mathrm{F}$ & $\mathrm{G}$ & \\
\hline 1 & -6 & 1 & 1 & 1 & 1 & 1 & 1 & \\
2 & & -5 & 1 & 1 & 1 & 1 & 1 & \\
3 & & & -4 & 1 & 1 & 1 & 1 & \\
4 & & & & -3 & 1 & 1 & 1 & \\
5 & & & & & -2 & 1 & 1 \\
6 & & & & & & -1 & 1 \\
\hline Total & & & & & & & \\
perlakuan & & & & & & & \\
\hline
\end{tabular}

Setelah itu dihitung jumlah kuadrat kompone (gugus) dengan rumus:

$$
J K i \frac{(\Sigma b T)^{2}}{r \Sigma b^{2}}
$$

Hasil jumlah kuadrat komponen (gugus) harus sama dengan jumlah kuadrat perlakuan. Total perlakuan diperoleh dari total perlakuan yang terdapat dalam data awal.

Teknik penentuan responden dilakukan secara sengaja acak (randomized judgement sampling) yang diambil dari masyarakat di dalam dan lingkungan Universitas Perjuangan dan universitas Pasundan Program studi teknologi pangan sebanyak 100 orang. Penilaian dilakukan dengan skala likert seperti terlihat pada Tabel 2.

Tabel 2. Skala Likert Kuesioner

Tidak suka

Suka

\begin{tabular}{|l|l|l|l|l|l|l|}
\hline 1 & 2 & 3 & 4 & 5 & 6 & 7 \\
\hline
\end{tabular}

Kuesioner yang dibuat menggunakan Skala Likert dengan pembobotan melalui skor 7-6-5-4-3-2-1.

Rumus yang digunakan untuk melakukan analisis data, yakni Nilai Tertimbang (Djoni, 2008) adalah:

$$
\begin{aligned}
& \text { NT }=\frac{\text { Nilai yang dicapai }}{\text { Nilai Ideal (maksimum) }} \text { X } 100 \text { persen } \\
& \text { Penentuan interval kelas untuk } \\
& \text { indikator dari variabel formulasinya } \\
& \text { sebagai berikut: }
\end{aligned}
$$

$$
\text { Klasifikasi }=\frac{\text { Skor Maksimal }- \text { Skor Minimal }}{\text { Jumlah Kategori }}
$$

\section{HASIL DAN PEMBAHASAN}

Analisis keragaman menunjukkan perbedaan yang nyata sehingga harus dilakukan uji lanjutan. Uji lanjutan untuk mengetahui perbedaan masing-masing gugus perlakuan menggunakan uji orthogonal kontras. Hasil uji keragaman dan orthogonal kontras pada Tabel 3. 
Tabel 3. Uji Ortogonal Kontras Tingkat konsumsi terhadap bau amis telur itik yang diperkaya antioksidan daun jintan

\begin{tabular}{|l|l|l|}
\hline Perlakuan & Bau Amis & Kesukaan \\
\hline Ulangan & 0.99 & 1.99 \\
\hline Perlakuan & $7.274^{* *}$ & $18.921^{* *}$ \\
\hline Komponen: & & \\
\hline 1 & $6.550^{* *}$ & $59.696^{* *}$ \\
\hline 2 & $6.527^{* *}$ & 0.267 \\
\hline 3 & $22.491^{* *}$ & $61.241^{* *}$ \\
\hline 4 & 0.029 & 0.077 \\
\hline 5 & $5.801^{* *}$ & $44.262^{* *}$ \\
\hline 6 & 3.026 & $44.436^{* *}$ \\
\hline
\end{tabular}

Sumber: Analisis data primer (2019)

Tabel 4. Hasil Uji Organoleptik Kesukaan, Warna dan Aroma

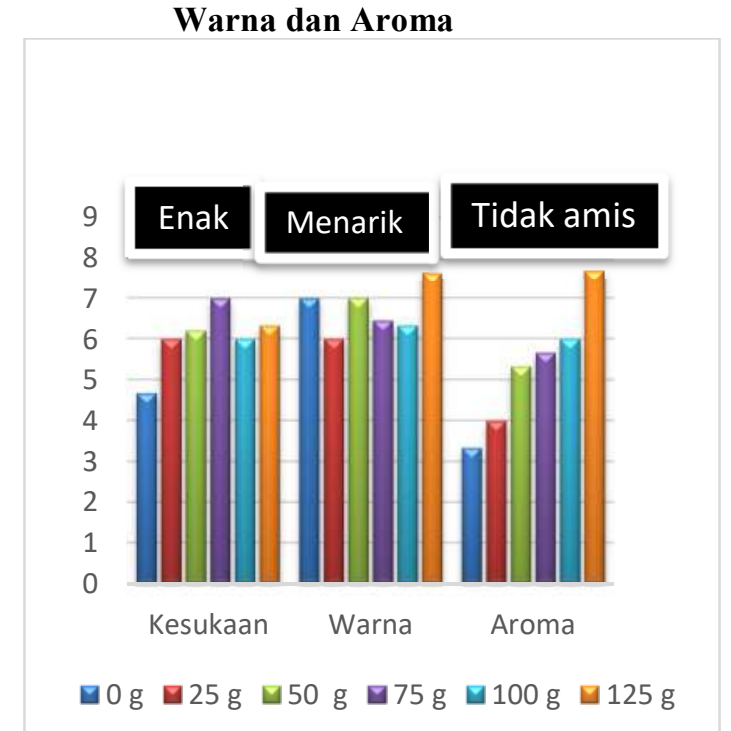

Sumber: Data primer diolah (2019)

Proses pembuatan telur asin dengan memanfaatkan daun jintan menunjukkan perbedaan yang nyata secara simultan. Hasil uji organoleptik dalam atribut rasa menunjukkan variasi perbedaan secara parsial di tiap komponennya. Pada atribut warna produk menunjukkan perbedaan yang nyata terutama pada komponen 1, 2, 3, 5. Hal yang paling memberikan perbedaan adalah pada atribut aroma. Aroma telur asin menjadi berbeda setelah diberikan perlakuan daun jintan. Perbedaan tersebut adalah mulai dari dosis terkecil sudah menunjukkan penurunan level aroma amisnya. Hal ini dimungkinkan oleh larutnya protein dan mikroorganisma penyebab bau amis menjadi jauh berkurang. Telur asin bisa lebih menyehatkan tanpa kehadiran mikroorganisma yang bersifat pathogen.

Pada atribut warna produk menunjukkan perbedaan yang nyata terutama pada komponen 2, dan 3. Pada atribut tesktur dan struktur daging dan telur itik yang diberi perlakuan daun jintan dan yang tidak diberikan perlakuan daun jintan tidak menunjukkan perbedaan yang nyata secara simultan. Namun pada struktur secara parsial, komponennya berpengaruh nyata yaitu pada perlakuan 3, dan 4. Hal yang paling memberikan perbedaan adalah pada atribut aroma. Aroma telur asin menjadi berbeda setelah diberikan perlakuan daun jintan. Perbedaan tersebut adalah mulai dari dosis terkecil sudah menunjukkan penurunan level aroma amisnya. Hal ini dimungkinkan oleh larutnya protein dan mikroorganisma. 
MENINGKATKAN KUALITAS DAN PREFERENSI KONSUMEN TELUR ITIK DENGAN CARA MENURUNKAN LEVEL BAU AMIS TELUR ASIN YANG DIPERKAYA ANTIOKSIDAN DAUN JINTAN (Plectranthus amboinicus L SPRENG)

Ristina Siti Sundari, Andri Kusmayadi, Reny Hidayati, Adnan Arshad

Tabel 5. Nilai Tertimbang dan Mutu Telur Itik Asin yang diperoleh

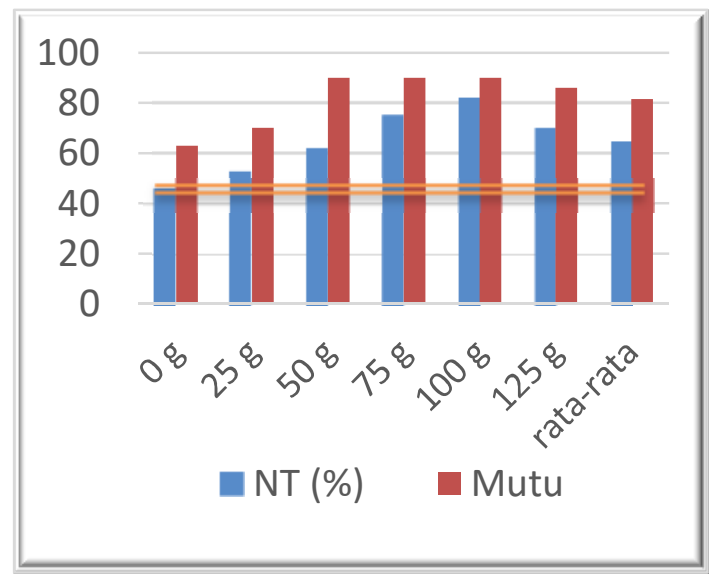

Sumber: Data primer diolah (2019)

Mutu telur asin meningkat setelah deperkaya dengan antioksidan yang berasal dari daun jntan dengan nilai tertimbang kategori tinggi. Hasil telur asin tanpa diberi perlakukan daun jintan dan yang diberi perlakuan daun jintan tampak berbeda seperti ditunjukkan pada Tabel 5.

Bahan baku penghilang bau amis sangat murah dan tidak mengganggu biaya produksi. Walaupun demikian, harga jual bisa dikondisikan mengingat mutu telur asin yang lebih tinggi dari telur asin yang konvensional. Dengan adanya produk telur asin bebas amis maka tingkat konsumsi telur asin akan meningkat. Diversifikasi pangan semakin berkembang. Preferensi konsumen terhadap telur asin bebas amis lebih tinggi walaupun mulai dari dosis rendah (Tabel 6).
Tabel 5. Preferensi Konsumen terhadap Telur Asin Bebas Amis

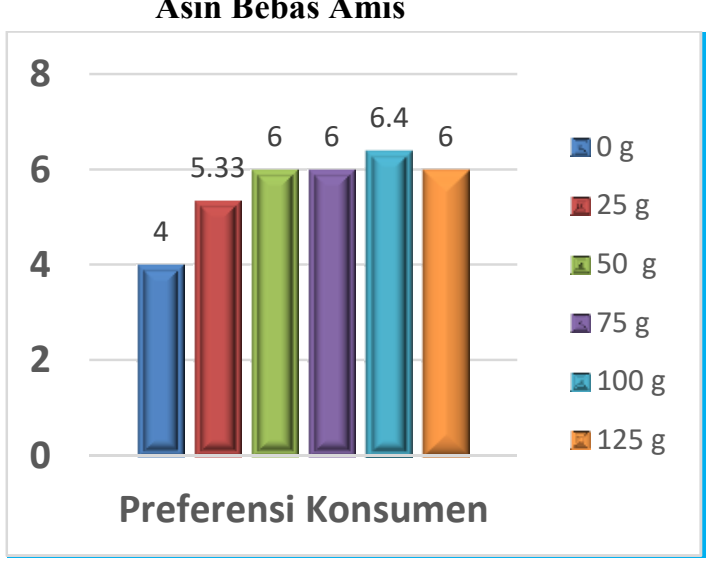

Sumber: Data primer diolah (2019)

Telur asin bebas amis cenderung lebih awet daripada yang konvensional.

\section{KESIMPULAN DAN SARAN}

\section{Kesimpulan}

Preferensi konsumen telur asin bebas amis lebih tinggi dibandingkan dengan telur asin konvensional. Penggunaan daun jintan pda semua dosis pemakaian mampu mengurangi level bau amis pada daging dan telur itik. Makin tinggi dosis pemberian makin berkurang bau amisnya. Aroma yang paling disukai dan hemat adalah pada dosis $50 \mathrm{~g}$ daun jintan dalam 40 butir telur itik.

\section{Saran}

Perlu dilakukan penelitian lebih lanjut mengenai penetrasi pasar produk agribisnis telur itik Cihateup yang diperkaya antioksidan daun jintan dan tingkat keawetannya. 


\section{UCAPAN TERIMA KASIH}

Ucapan terimakasih yang tak terhingga kepada lembaga Ristekdikti yang telah membantu pendanaan hibah PDP untuk kelancaran penelitian ini.

\section{DAFTAR PUSTAKA}

Alagawan, M., El-Hack, MEA, Farag, MR, Tiwari, R., Dhama, K. Biological Effects and Modes of Action of Carvacol in Animal and Poultry Production and Health - A Review

Apendi Kusuma Widayaka, Juni Sumarmono. 2013. Jurnal Ilmiah Peternakan 1(1):142-150, April 2013142 Fakultas Peternakan. Universitas Jenderal Soedirman, Purwokerto

BULOG. 2018. Ketahanan Pangan. http://www.bulog.co.id/ketahananp angan.php diunduh 17 april 2019

Dalimartha Setiawan (2007). Atlas Tumbuhan Obat Indonesia. Jakarta: Puspa Swara. ISBN 979-1133-14$\underline{X}$.

Delimartha dan Setiawan. 2008. Atlas Tumbuhan Obat. Pustaka Bunda. Jakarta.

Dharma, A.P. (1987). Indonesian Medicinal Plants. [TanamanTanaman Obat Indonesia] (Dalam bahasa Inggris). Jakarta: Balai Pustaka.ISBN 979-407-032-7.

Dudi. 2007. Identifikasi Sifat Kuantitatif Itik Cihateup sebagai Sumberdaya Genetik Unggas Lokal. Jurnal Ilmu Ternak, Juni 2007, Vol. 7 NO. 1, 39 - 42. Fakultas Peternakan Universitas Padjadjaran

Dyastuti, E, Nofiani, R, Ardiningsih, P. 2013. Uji Organoleptik Cincalok Dengan Penambahan Serbuk Bawang Putih (Allium sativum) dan Serbuk Cabai (Capsium annuum
L). Pustaka: JKK, tahun 2013, volume 2 (2), halaman 70-73 ISSN 2303-1077 70. Program Studi Kimia, Fakultas MIPA, Universitas Tanjungpura, Jl. Prof. Dr. H. Hadari Nawawi, Pontianak Indonetwork. 2015. Tanaman Bangun-bangun.

http://www.indonetwork.co.id/lang geng sari farm/4344299

Harapan. 2017. Manfaat Daun Jintan. http://tanaman--

herbal.blogspot.com/2017/07 /manfaat-daun-jinten-coleusamboinicus.html. Diunduh 20 Maret 2019

Hasanah, I. 2016. Aktifitas Anti Streptococcus mutans Ekstaks Kulit Buah Naga. Repository Universitas Jember.

Hii, C., Lawi, CL., Suzannah, S., Misnawi, and Clokei, M. 2009. Polyphenol in Cocoa (Theobroma cacao L). Asian Journal of Food and Agro Industry. Vol 2 (4): 702722

Ide Boedie. 2008. Menghilangkan Bau Amis Telur Bebek. //ideboedie.blogspot.com

/2008/06/menghilangkan-bau-amistelur-bebek.html/ Diunduh 13 Maret 2018.

Kartika, Bambang, P. Hastuti, dan Supartono, 1988, Pedoman Uji Inderawi Bahan Pangan, Pusat Antar Universitas, Pangan dan Gizi, Universitas Gadjah Mada, Yogyakarta

Keng. 1978.

Matitaputty, P.R. dan Suryana. 2010. Karakteristik Daging Itik dan Permasalahan serta Upaya Pencegahan Off-Flavor akibat Oksidasi Lipida. Wartazoa Vol. 20 (3) 2010 Hlm. 130-138.

Matitaputty, P.R. dan Suryana. 2014. Tinjauan tentang Performans Itik Cihateup (Anas platirhynchos 
Jaanica) sebagai Sumberdaya

Genetik Unggas Lokal di Indonesia. Wartazoa Vol. 24 (4) 2014 Hlm. 171-178. DOI:http://dx.doi.org/10.14334/war tazoa.v24i4.1088.

Muniroh, L., Martini, S., Nindya, TS., Solfaine, R. 2013. Efek Anti Radang dan Toksisitas Akut Ekstrak Daun Jintan (Plectranthus amboinicus) pada Tikus yang Diinduksi Arthritis. Makara Seri Kesehatan, 2013, 17(1) hlm. 33-40.

Norazsida, R., Pakeer, O., Taher, M., 2017. The Antimalarial Properties of Essential Oil of the Leaves of Malaysian Plectranthus amboinicus (Lour) Spreng in Mice Infected with Plasmodium berghei.

Ross, Z, M., E.A O'Gara, H.V. Sleightholme, D.J. Hill, and D.J. Maslin, 2001, Antimicrobial Properties of Garlic Oil against Human Enteric Bacteria: Evaluation of Methodologies and Comparisons with Garlic Oil Sulfides and Garlic Powder, Appl, Environ, Microbiol, Vol. 67(1): 475-80

Rukmiasih, N. Ulupi, W. Indriani. 2015. Sifat Fisik, Kimia dan Organoleptik Telur Asin Melalui Penggaraman dengan Tekanan dan Konsentrasi Garam yang Berbeda.Jurnal Ilmu Produksi dan Teknologi Hasil Peternakan ISSN 2303-2227 Vol. 03 No. 3 Oktober 2015 Hlm: 142145 http://journal.ipb.ac.id/index.php/ip thp/article/viewFile/14497/pdf

Silalahi, M. 2018. Plectranthus amboinicus (Lour.) Spreng sebagai Bahan Pangan dan Obat serta Bioaktifitasnya. JDP. Vol. 11(2) Juli 2018. Hlm. 123-138.

Sholikhah, E.H., 2009, Efektivitas Campuran Meniran Phyllanthus Niruri dan Bawang Putih (Allium sativum) dalam Pakan untuk Pengendalian Infeksi Bakteri Aeromonas hydrophila pada Ikan Lele Dumbo Clarias, Fakultas Perikanan dan Ilmu Kelautan, Institut Pertanian Bogor, Bogor

Susiwi, S. 2009. Regulasi Pangan. Penialian Organoleptik. http://file.upi.edu/Direktori/FPMIP A/JUR. PEND. KIMIA/19510919 1980032-SUSIWI/SUSIWI32\%29. Penilaian Organoleptik.pd f. Diunduh 15 April 2019.

UN. 2015. Achieving zero hunger and ending poverty by 2030. FAO and the 17 Sustainable Development Goals.

https://sustainabledevelopment.un.o $\mathrm{rg} /$ content/documents/2205FAO\%2 0and \%20the\%2017\%20SDGs.pdf

Wikipedia. 2015. Daun Jintan. http://id.wikipedia.org/wiki/Daun i intan diunduh 13 Mei 2018 